\title{
Current status of bluetongue in Europe
}

\author{
WIESŁAW NIEDBALSKI
}

Department of Foot and Mouth Disease, National Veterinary Research Institute, Wodna 7, 98-220 Zduńska Wola, Poland

\section{Niedbalski W. \\ Current status of bluetongue in Europe}

Summary

The article reviews the present epidemiological situation of bluetongue (BT) in Europe. After a four year break, disease caused by BTV serotype 8 reappeared in west Europe. On 11 September 2015, an outbreak of BTV8 was confirmed in central France (Allier department), and four weeks later, on 6 October, 45 outbreaks of 118 cases were confirmed in Allier, Puy-de-Dome, Creuse, Nicvre and Cher departments. Besides, BT caused by BTV1 and BTV4 is still circulating in some regions of southern and south-eastern Europe. Since 2013 disease caused by BTV1 was spreading extensively over the central and south Italy and in the south of French Corsica island. BTV1 cases were also confirmed in the southwest Spain (Cáceres and Toledo provinces) and at the end of 2014 BTV1 outbreak has been reported in a single (sentinel) holding in the region of Cadiz. More recently, BTV1 has been detected in Croatia (Sibenik area, Central Dalmatia). Furthermore, multiple outbreaks of BTV4 in cattle and sheep were reported across many regions of southern Europe. In the period from May to July 2014, 125 outbreaks of BTV4 have been confirmed in Greece (Peloponnese and Evros regions). The first suspicion of BTV4 in Spain was reported in September 2014 and at the beginning of December, 351 outbreaks were confirmed in the southern part of country. On 4 July 2014 the first outbreak of BTV4 was reported at the southeastern Bulgaria (Burgas Region), near the border with Turkey and by the end of 2014 disease was confirmed in all 28 administrative districts of Bulgaria. Moreover, on 23 August 2014 the first outbreak of BTV4 was confirmed in south-east of Romania (Buzau county) and as for 3 December 2014 disease was confirmed in 34 from 42 counties of this country, totally 1128 outbreaks and 4075 affected animals. After a few months break, in September BTV4 reappeared in Botosani county in northern Moldavia and on 6 October 14 outbreaks of 26 cases in cattle were confirmed. BTV4 outbreaks have also been reported in many other regions of Balkans countries: Albania, Serbia, Croatia, Montenegro, Macedonia and Bosnia and Herzegovina. BTV4 infected animals were also detected in Hungary; the first outbreak was reported on 14 October 2014 in Csongrád county. Up to 5 December, 77 outbreaks (30 primary and 47 secondary) in 5 counties were confirmed. In September 2015, BTV4 reappeared and on 6 October, 12 outbreaks of 33 cases in cattle in Tolna, Baranya and Somogy county were reported. In total, in the whole Balkan/Peloponnese/Central Europe region, over 5500 outbreaks have been confirmed. Disease control measures, such as movement restrictions are in place although vaccination is not being used at present in the Eastern EU Member States for BTV4 because of a combination of vaccine availability, cost and farmer acceptance. BT restriction zones have been regularly updated and as of 6 October 2015, 12 zones were defined.

Keywords: bluetongue, epidemiology, Europe

Bluetongue (BT) is an infectious but non-contagious, insect-borne viral disease of ruminants, mainly sheep and less frequently of cattle, goats, buffalo, deer, dromedaries, and antelopes (20). It is caused by bluetongue virus (BTV), a RNA virus belonging to the Orbivirus genus in the Reoviridae family (13) and transmitted by bitting midges of the genus Culicoides (11). BTV is a small (about $70 \mathrm{~nm}$ in diameter) icosahedral virus with a ten-segmented, double-stranded RNA (dsRNA) genome (21), which is packaged within an icosahedral nucleocapsid composed of seven structural proteins (16). Twenty-six immunologically distinct serotypes of BTV have been identified worldwide $(2,8,19)$.
Recently, a new BTV ("serotype 27") genetically diverse from other BTVs was detected in goats on Corsica, France (24). Sequence analysis confirmed the closest relationship between sequences of the novel BTV serotype and BTV25 and BTV26, discovered in Switzerland and Kuwait (4). BT is classified as a notifiable disease by the Office International des Epizooties (OIE), according to Council Directive 82/894/EEC of 21 December 1982, due to its potential rapid spread and serious economic consequences in affected countries. BT have a negative economic impacts, mainly due to the effect on animals (morbidity, mortality, reproductive failure, reduction in milk yields and weight gain) 
and, most of all, to the disruption of international trade of animals and animal products (17). The most common symptoms of BT include fever, catarrhal stomatitis, rhinitis, coronitis, enteritis, laminitis, facial and intermuscular oedema, pleural and pericardial effusion, pulmonary oedema, and necrosis of skeletal and cardiac muscle. The mortality rate can vary from $0 \%$ to $30 \%$, but may reach $75 \%$ (9). These symptoms are commonly seen in sheep and in some deer species but rarely in cattle and goats. Cattle, as well as goats and deer, are thought to act as a reservoir for the virus (5).

BTV is endemic in many tropical, sub-tropical and temperate regions of the world (America, Australia, Africa and some regions of Asia), between latitudes $40^{\circ} \mathrm{S}$

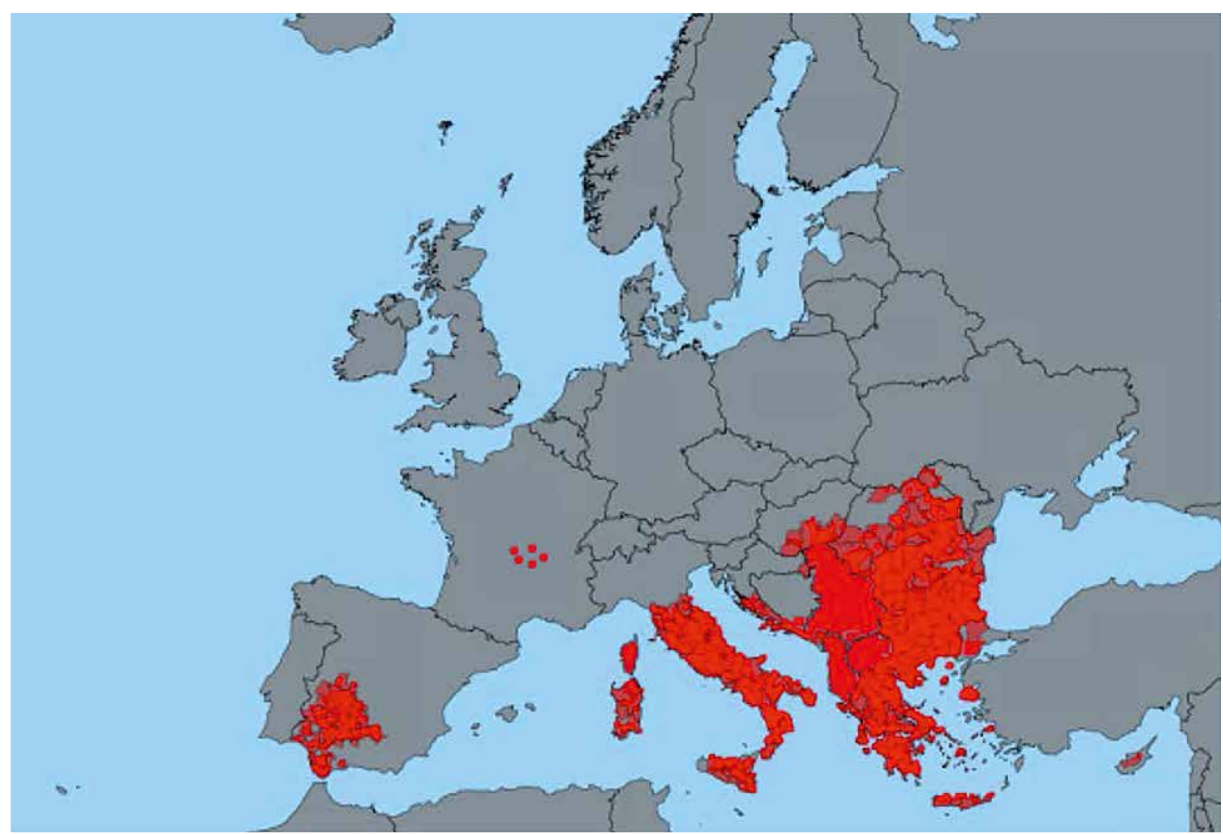

Fig. 1. BTV outbreaks in Europe from January 2014 to October 2015. Modified, according to the Animal Disease Notification System - ADNS (http://ec.europe.eu)

and $53^{\circ} \mathrm{N}$, during times of the year that are optimal for vector activity $(11,22)$. Historically, Europe has experienced only sporadic incursions of BT, involving a single virus serotype on each occasion (10). However, since 1998 BTV spread northwards into the Mediterranean Basin, where five BTV serotypes $(1,2,4,9$ and 16) have been identified (12). Climate change has been proposed as a potential driver of this northward expansion of BTV from Africa and Asia into Mediterranean Europe (15). In the summer of 2006, for the first time, the BTV has crossed latitude $50^{\circ} \mathrm{N}$ and BT outbreaks caused by BTV serotype 8 occurred in North-Western Europe: the Netherlands, Belgium, Germany, France, and Luxembourg (23). In 2007-2008, the BT situation changed for the worse, BTV8 spread to the other regions of Europe and the number of outbreaks increased rapidly (about 50000 cases of BT were reported). Additionally, two new BTV serotypes, BTV1 and BTV6, were detected (23). However, the implementation of BT compulsory vaccination programmes in Europe in spring 2008 resulted in reduction of BTV8 cases to 350 in 2009, 19 in 2010 and only one case of BT caused by BTV8 in 2011 in north Sardinia (Italy) (http://eubtnet.izs.it/ btnet.reports/BTV8.htlm). However, after a four year break, on 11 September 2015 an outbreak of BTV8 was confirmed again in the European Union (EU) in central France, Allier region (http://www.oie.int/wahis_2/ public/wahid.php/). The first clinical signs (facial oedema, respiratory problems and increased temperature) were observed on 21 August in a single sheep at the holding in a commune Louroux-de-Bouble. Samples tested positive from 5 out of 175 sheep and 27 out of 147 cattle. In the following weeks, the disease spread and on 06 October 2015, 45 outbreaks of 118 cases (109 in cattle and 9 in sheep) of BTV8 were confirmed in departments Allier, Puy-de-Dome, Creuse, Nievre and Cher (Fig. 1). According to the European Commission regulation (EC) no 1266/2007 the French Ministry of Agriculture has established and implemented a restriction zone consisting of $20-\mathrm{km}$ radius infected zone, protection zone (at least $100 \mathrm{~km}$ radius around outbreak of BT) and $150-\mathrm{km}$ radius surveillance zone where there is a restriction of animal movements, active surveillance and a ban of gatherings. Additionally, the French government and livestock sectors have in place a vaccination strategy and 1.3 million doses of vaccine will be made available to prevent spread of the disease. The results of the epidemiological report suggest this is not a recent import of infected animals, but whether this is the result of unreported virus circulation (possibly in livestock or wildlife), a vaccine problem or imported infected midges is not known. More investigations will be carried out in the region and the neighbouring areas to determine the source of infection. Until the origin of disease and the extent of spread are clear, it is difficult to assess whether the recurrence of BTV8 in France signifies an increase in risk of BT in Europe (http:// www.promedmail.org/).

\section{The current BT epidemiological situation}

Besides the last BTV8 outbreaks in France, the disease caused by BTV serotypes 1 and 4 is still circulating in some regions of southern and south-eastern Europe (Fig. 1). According to the information of the Directoriate General for Health and Consumer Affairs - European Commission (DG SANCO), since 2013 disease caused by BTV1 was spreading extensively over the central and south Italy and as for 8 January 2015 about 1400 outbreaks has been confirmed (940 in sheep/goats and 447 in cattle/buffaloes) (http:// 
ec.europa.eu). Molecular epidemiology of BTV1 circulating in mainland Italy shown to be nearly identical to the virus isolated in Tunisia in 2011 (6) and BTV1 and BTV4 newly isolated Sardinian strains were identical and cluster together with recent BTV1 strain circulating in the Mediterranean Basin and BTV4 strain isolated in Tunisia in 2007 and 2009 (7). At the beginning of September 2013, sheep located in the south of French Corsica island showed clinical sign of BTV1 infection (18) and by March 2014, 169 BTV1 outbreaks were reported (24). Phylogenetic studies showed that the sequences of this strain is closely related to BTV1 strain that circulating on the Mediterranean Basin and on Sardinia in 2012 (18). Furthermore, BTV1 cases were noticed in the southwest Spain in Cáceres and Toledo provinces (14) and at the end of 2014 BTV1 has also been reported in the region of Cadiz (Andalusia) in a single (sentinel) holding presumably as a result of incursion from Morocco into Gibraltar region (http:// www.oie.int). Moreover, in November 2014, the first positive result on BTV1 was detected in sheep in Croatia in Slibenik-Knin County and later on island Lasovo in Dubrovnik -Neretva County. More recently, in April 2015, another outbreak of BTV1 has been detected in sheep in Central Dalmatia, Sibenik area (http://ec.europa.eu).

In addition to the BTV1, multiple outbreaks of BTV4 has been reported in cattle and sheep across many regions of southern Europe (Fig. 1). On 30 May 2014, the first outbreak of BTV4 was confirmed in southern part of mainland Greece (region of Peloponnese, prefecture of Lakonia). In the period from May to July 2014, in Peloponnese and Evros regions, 125 outbreaks of BTV4 have been noticed: sixty three in Lakonia, 49 in Arkadia, 11 in Messina regions and one outbreak in Argolida and Kortinthia regions, all in sheep (http:// www.oie.int). Sequence analysis on BTV4 isolated from the latest Greek outbreaks suggest the strain present is a western lineage, but is not closely related to those from Greece and Cyprus several years ago and outbreaks could be the results of several incursions. The virus is a reassortant with the segments derived from BTV1, BTV2 and BTV4 isolates circulating in the West Mediterranean and North Africa. This mechanism of genetics recombination of genomic material is not unusual in the bluetongue virus family; gene re-assortment between BTV strains occurs frequently (http:// www.gov.uk). The first suspicion of BTV4 in Spain was reported in September 2014, involving a different virus strains. At the beginning of December 2014, 351 BTV4 outbreaks were confirmed in southern Spain (1).

On 4 July 2014 the first outbreak of BTV4 has also been reported at the southeastern Bulgarian border (Burgas Region, near the border with Turkey) and by the end of 2014 disease was confirmed in all 28 administrative districts of this country. Totally, about 7300 herds of susceptible animals has been affected, including 6061 herds of sheep, 808 herds of bovine and 391 herds of goats, consisting of 533 733, 26036 and 12173 animals, respectively. No new outbreaks of BT were noticed in Bulgaria to October 2015. The results of sequence analysis of Bulgarian BTV4 strain suggested that it was also a western strain, but with enough differences to suggest a separate incursion to that in Greece (http://www.gov.uk). Additionally, on 11 August 2014 BTV4 outbreak was reported in Kirklareli Province (Marmara region) in north eastern Turkey near the border with Bulgaria; 125 cases of BTV4 were confirmed in sheep (http://www.oie.int). Moreover, on 23 August 2014 the first outbreak of BTV4 was reported in south-east of Romania (Buzau county) and as of 3 December 2014 disease was confirmed in 34 of 42 counties of this country, totally 1128 outbreaks of 4075 affected animals (http://ec.europa. eu). After a few months break, in September 2015, BTV4 reappeared in Botosani county in northern Moldavia and on 6 October 2015, 14 outbreaks of 26 cases in cattle were confirmed in this region (http:// www.oie.int). BTV4 outbreaks were also reported across many regions of other Balkans countries: Albania, Serbia, Croatia, Montenegro, Macedonia and Bosnia and Herzegovina. On 12 September 2014 BTV4 outbreak was reported in sheep and goats in southwestern part of Albania in Korce region (Kolonia district) and to the end of 2014, 2463 outbreaks of BT were confirmed. The first outbreak of BTV4 in Croatia was reported on 27 October 2014 in Dubrovnik - Neretva county. Until 31 October animals with clinical signs were identified on 13 holdings distributed on the area of $150 \mathrm{~km}$ (from Konavle to Peljesac peninsula) and totally 26 outbreaks of BTV4 were confirmed. Then, between October 2014 and April 2015, 80 outbreaks of 253 cases in 5 counties (Vukovar-Srijem, Zadar, Sibenik-Knin, Split-Dalmatia and Dubrovnik-Neretva) were reported. On 25 September 2015 BTV4 reoccurred in Split-Dalmatia county and 1 outbreak of 1 cases in sheep was confirmed (http://www.oie.int/ wahis_2/public/wahid.php/).

Furthermore, on 4 September 2014 the first outbreak of BTV4 was noticed in Serbia, most reports of disease have involved in the eastern part of country, particularly in Pirotski and Borski districts. Serbian cases reached 425 in the latest report, mostly in sheep, with $40 \%$ sheep fatality rate (http://www.oie.int). In October 2014 BTV4 outbreak was confirmed in Montenegro and up to 14 November totally 14 outbreaks were reported, mainly in Danilovgrad and Podgorica regions. Additionally, on 28 November one outbreak of BTV4 was confirmed in Bosnia and Herzegovina in Neum region on Adriatic sea coast. Moreover, in October 2014 over 800 sheep have died from BTV4 infection in Macedonia (regions of Kavadarci and Rosomanand) and at the end of 2014, 14 cases of BTV4 in south eastern Macedonia (Gevgelija municipality near the city of Dojran) were confirmed (http://www. oie.int). BTV4 infected animals has also been diag- 
nosed in Hungary; the first outbreak was reported on 14 October 2014 in Csongrád county. Up to 10 January 2015, 77 outbreaks ( 30 primary and 47 secondary) in 5 counties (Csongrád, Bács-Kiskun, Békés, Tolna and Baranya) were reported. In September 2015, BTV4 reappeared in Hungary and on 6 October, 12 outbreaks of 33 cases in cattle in Tolna, Baranya and Somogy county were confirmed (http://www.oie.int/wahis 2/ public/wahid.php/).

In total, in the whole Balkan/Peloponnese/Central Europe region, over 5500 outbreaks have been reported. Council Directive 2000/75/EC lays down control rules and measurements to combat BT in EU, including the establishment of protection and surveillance zones and a ban on animals of the susceptible species leaving those zones. Disease control measures, such as movement restrictions are in place although vaccination is not being used at present in the Eastern EU Member States for BTV4 because of a combination of vaccine availability, cost of vaccination and farmer acceptance. Vaccines are based on one of the outer proteins of the virus capsid which also determines the serotype, therefore any BTV4 vaccine would be effective for these new outbreaks. Inactivated BTV4 vaccines, as well as BTV1 and BTV2, are approved for use in the EU but there are only small, limited amounts of stocks currently available and new production and licencing would take time, depending on commercial demand. Besides, Commission Regulation (EC) No 1266/2007 introduces the obligation for the of EU Member States to carry out BT monitoring and surveillance programmes aimed at detecting any possible incursions of BTV or determining the seasonally vector free period through entomological surveillance (http://www.ec.europe.eu).

\section{BT restriction zones in Europe}

According to Article 6.4 of the European Commission Regulation (EC) No 1266/2007 of 26 October 2007, Member States shall draw up and keep updated a list of the restricted zones in their territory. The list of restriction zones in Europe as for 6 October 2015 is as follows (Fig. 2):

- Zone F - BTV8, France: central regions of country, departments Allier, Puy-de-Dome, Creuse, Nievre and Cher,

- Zone G - BTV1, 2, 4, 16, Italy: region Calabria,

- Zone H - BTV serotype not specified, Malta: whole territory,

- Zone I-BTV1 and 4, Croatia: the island of Lastovo in Split Dalmatia county, Portugal: Algarve region, Spain: autonomous com- munity Andalusia (provinces Cordoba, Cadiz, Huelva, Malaga, Seville, Jaen, Granada), autonomous community Castilla-La Mancha (provinces Toledo and Ciudad Real), autonomous community Castilla and Leon (provinces Avilla and Salamanca) and autonomous communities Extremadura (provinces Badajoz and Caceres,

- Zone J - BTV1, Italy regions: Lazio, Liguria, Marche, Toscana and Emilia Romagna and Portugal: whole mainland territory (excl. Zone I),

- Zone T-BTV1, 2, 4, 8 and 16, France: departments Haute-Corse and Corse-du-Sud, Zone X - BTV4 and 16, Cyprus: whole territory, Greece: islands of Dodecanese and Samos,

- Zone Z - BTV1 and 16, Italy: regions Abruzzo, Basilicata, Campania, Lazio (Roma and Viterbo), Molise, Sardegna, Sicilia and Umbria,

- Zone A2 - BTV1, 2 and 16, Italy: region Campania (Salerno),

- Zone A3 - BTV4, Greece: the entire territory of Greece except for the regional units of Cyclades island and Chios, Bulgaria: whole territory, Romania: whole territory, Hungary: counties: Komaron-Esztergom, Pest, Nograd, Heves, Somogy, Fejer, Jasz-Nagykun-Szolnok, Bekes, Baranya, Tolna, Bacs-Kiskun, Csongrad, Zala, Veszprem, Hajdu-Bihar, Vas and species parts of counties: Gyor-Moson-Sopron, Borsod-Abauj-Zemplen, Szabolcs-Szatmar-Bereg, Slovakia: districts Rimavska Sobota, Ludenec, Zvolen, Vel'ky Krits, Levice, Nove Zamky, Komarno, Croatia: whole territory, Spain: autonomous community Castilla and Leon (provinces Avilla and Salamanca), autonomous community Madrid, autonomous community Castilla-La Mancha (provinces Toledo and Ciudad Real), autonomous communities Extremadura (provinces Caceres and Badajoz),

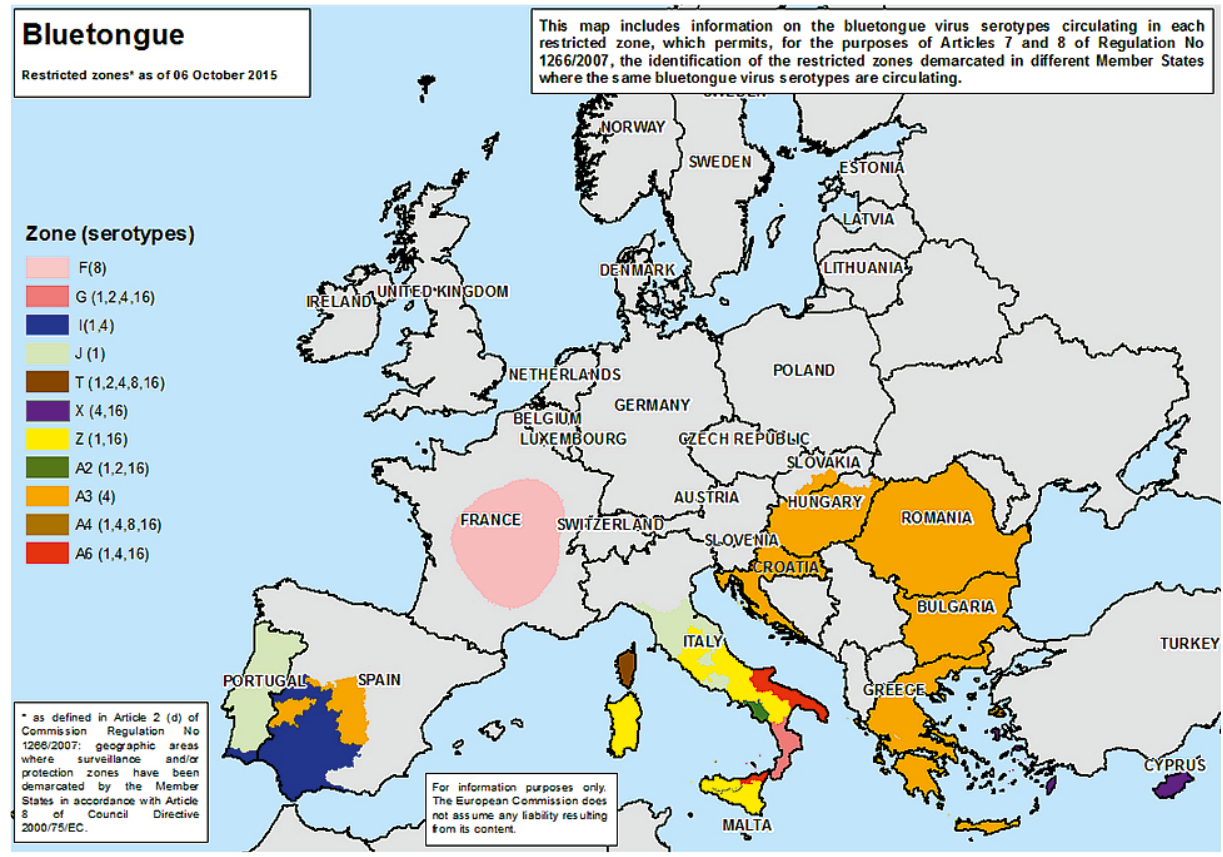

Fig. 2. Bluetongue-restricted zones in Europe as of 6 October 2015 (http://ec.europa.eu/ food/animal/diseases/controlmeasures/bt_restrictedzones-map.jpg) 
- Zone A4 - BTV 1, 4, 8 and 16, Greece: the Island Lesbos,

- Zone A6 - BTV1, 4 and 16, Italy: region Puglia, Sicilia (Province of Messina).

Restriction zones have been regularly updated and these limit live animal movements but the zones will not be able to prevent spread by vectors. In some southerly regions, a mid autumn means vector numbers may remain high for some time to come, while in central Europe, for example Bulgaria, the temperature has started to drop, the first snow has been reported and this should reduce the infection pressure. Both Romania and Bulgaria are looking at the possibility of vaccination campaigns to start in 2015 , once vaccine availability and financial arrangements are in place. Vaccination against BTV1 is not mandatory in Italy (except in Sardinia) and is mainly in sheep and goats or animals for movement, while Spain has both compulsory and voluntary BTV4 vaccination zones, depending on the level of risk. It is possible that in the near future the disease will spread in the Northern Europe. The population of livestock in these areas is dense and will not be protected by vaccination. Judging by the reports coming from Bulgaria and Romania, within herd prevalence is over $30 \%$ in sheep flocks, $4 \%$ in cattle herds (http://ec.europa.eu).

\section{References}

1.Arsevska E., Balenghien T., Breard E., Garros C., Lancelot R., Sailleau C., Zientara S.: Fievre catarrhale ovine en Europe en 2014: epizootie dans les Balkans, progression de la circulation en Itale et en Espagne. Bull. Epid. Santé Anim. Alim. 2015, 69, 20-24.

2. Chaignat V., Worwa G., Scherrer N., Hilbe M., Ehrensperger F., Batten C., Cortyen M., Hofmann M., Thuer B.: Toggenburg Orbivirus, a new bluetongue virus: initial detection, first observation in field and experimental infection of goats and sheep. Vet. Microbiol. 2009,138, 11-19.

3. Guis H., Caminade C., Calvete C., Morse A. P., Tran A., Baylis M.: Modeling the effects of past and future climate on the risk of bluetongue emergence in Europe. J. R. Soc. Interface 2012, 9, 339-350.

4. Jenckel M., Breard E., Schulz C., Sailleau C., Viarouge C., Hoffmann B., Hoper D., Beer M., Zientara S.: Complete coding genome sequence of putative novel bluetongue virus serotype 27. Genome Announc. 2015, 3(2):e00016-15. doi:101128/genomeA.00016-15.

5. Lopez-Olivera J. R., Falconi C., Fernandez-Pacheco P., Fernandez-Pinero J., Sanchez M. A., Palma A., Herruzo I., Vicente J., Jimenez-Clavero M. A., Arias M., Sanchez-Vizcaino J. M., Gortazar C.: Experimental infection of European red deer (Cervus elaphus) with bluetongue virus serotypes 1 and 8 . Vet. Microbiol. 2010, 145, 148-152.

6. Lorusso A., Sghaier S., Ancora M., Marcacci M., Di Gennaro A., Portanti O. Mangone I., Teodori L., Leone A., Camma C., Petrini A., Hammami S., Savini $G$.: Molecular epidemiology of bluetongue virus serotype 1 circulating in Italy and its connection with northern Africa. Infect. Genet. Evol. 2014, 28 , 144-149.

7.Lorusso A., Sghaier S., Carvelli A., Di Gennaro A., Leone A., Marini V., Pelini S., Marcacci M., Rocchigiani A. M., Puggioni G., Savini G.: Bluetongue virus serotypes 1 and 4 in Sardinia during autumn 2012: New incursions or re-infection with old strains? Infect. Genet. Evol. 2013, 19, 81-87.

8. Maan S., Maan N. S., Nomikou K., Batten C., Antony F., Belaganahalli M. N., Samy A. M., Reda A. A., Al-Rashid S. A., El Batel M., Oura C. A., Mertens P. P.: Novel bluetongue virus serotype from Kuwait. Emerg. Infect. Dis. 2011, $17,886-889$

9. Maclachlan N. J., Drew C. P., Darpel K. E., Worwa G.: The pathology and pathogenesis of bluetongue. J. Comp. Phys. 2009, 141, 1-16.

10. Mellor P. S., Boorman J.: The transmission and geographical spread of African horse sickness and bluetongue viruses. Ann. Trop. Med. Parasitol. 1995 89, $1-15$.
11. Mellor P. S., Boorman J., Baylis M.: Culicoides biting midges: their role as arbovirus vectors. Annu. Rev. Entomol. 2000, 45, 307-340.

12. Mellor P. S., Wittmann E. J.: Bluetongue virus in the Mediterranean Basin 1998-2001. Vet. J. 2002, 164, 20-37.

13. Mertens P. P., Maan S., Samuel A., Attoui H.: Orbivirus, Reoviridae, [in:] Fauquet C. M., Mayo M. A., Maniloff J., Desselberger U., Ball L. A. (eds): Virus taxonomy: VIIIth report of the ICTV, Elsevier/Academic Press, London 2005, 466-483.

14.Perez De Diego A. C., Sanchez-Cordon P. J., Sanchez-Vizcaino J. M.: Bluetongue in Spain: from the first outbreak to 2012.Transbound. Emerg. Dis. 2014, 61, e1-e11.

15. Purse B., Mellor P. S., Rogers D. J., Samuel A. R., Mertens P. P., Baylis M. Climate change and the recent emergence of bluetongue in Europe. Nat. Rev. Microbiol. 2005, 3, 171-181.

16. Roy P.: Bluetongue virus proteins and particles and their role in virus entry, assembly, and release. Adv. Virus Res. 2005, 64, 69-123.

17. Saegerman C., Berkvens D., Mellor P. S.: Bluetongue epidemiology in the European Union. Emerg. Infect. Dis. 2008, 14, 539-544.

18. Sailleau C., Viarouge C., Breard E., Perrin J. B., Doceul V., Vitour D., Zientara $S$.: Emergence of bluetongue virus serotype 1 in French Corsica island in September 2013. Transbound. Emerg. Dis. 2014, doi: 10.1111/tbed.12207.

19. Schwartz-Cornil I., Mertens P. P., Contreras V., Hemati B., Pascale F., Breard E., Mellor P. S., MacLachlan N. J., Zientara S.: Bluetongue virus: virology, pathogenesis and immunity. Vet. Res. 2008, 39, 46.

20. Verwoerd D. W., Erasmus B. J.: Bluetongue, [in:] Coetzer J. A. W., Thomson G. R., Tustin R. C. (eds.): Infectious diseases of livestock with special reference to Southern Africa. Oxford University Press, Southern Africa, Cape Town 1994, 443-459.

21. Verwoerd D. W., Louw H., Oellermann R. A.: Characterization of bluetongue virus ribonucleic acid. J. Virol. 1970, 5, 1-7.

22. Walton T. E.: The history of bluetongue and a current global overview. Vet. Ital. 2003, 40, 31-38.

23. Wilson A. J., Mellor P. S.: Bluetongue in Europe: past, present and future Philos. Trans. R. Soc. Lond. B Biol. Sci. 2009, 364, 2669-2681.

24.Zientara S., Sailleau C., Virouge C., Hoper D., Beer M., Janckel M., Hoffmann B., Romey A., Bakkali-Kassimi L., Tablet A., Vitour D., Breard E.: Novel bluetongue virus in goats, Corsica, France, 2014, Emerg. Infect. Dis. 2014, 20, 2123-2125.

Corresponding author: dr hab. Wieslaw Niedbalski, assoc. prof., Wodna 7, 98-220 Zduńska Wola; e-mail: wieslaw.niedbalski@piwzp.pl 